Dr MARTIN PREVIŠIĆ, docent

Filozofski fakultet, Sveučilište u Zagrebu

Zagreb, Republika Hrvatska

martinprevisic@gmail.com

originalan naučni rad

UDK: 355:929 Опачић С.(093.2)

primljeno: 31. mart 2019.

343.819.7(497.13)"1950":929(093.2)

prihvaćeno: 22. maj 2019.

https://doi.org/10.29362/ist20veka.2019.2.pre.177-194

\title{
PAD STANKA OPAČIĆA ĆANICE - OD KORDUNA DO LOGORA I NATRAG
}

„Drug Ćanica jaši konja vrana, za njim ide četa partizana. “1

APSTRAKT: U članku se analizira politički pad Stanka Opačića Ćanice 1950. godine, njegovo hapšenje i isljeđivanje, internacija na Goli otok te njegovo praćenje od strane organa državne sigurnosti nakon izlaska iz logora. Rad se temelji na arhivskim dokumentima Službe državne sigurnosti (SDS/Udbe), znanstvenoj i publicističkoj literaturi, objavljenim dokumentima te usmenim svjedočenjima logoraša Golog otoka. Cilj rada je doprinos analizi uzroka i posljedica pada Stanka Opačića Ćanice, koji se usko veže uz hapšenje „ministarske trojke“, grupe srpskih ministara u vladi Narodne republike Hrvatske (Žigić, Brkić, Opačić). Ovaj slučaj, dakako, dio je šireg problema čistki zbog stvarne i navodne podrške Sovjetskom Savezu tijekom sukoba Tito-Staljin.

KLJUČNE RIJEČI: Stanko Opačić Ćanica, Rade Žigić, Duško Brkić, Udba, Goli otok, Jugoslavija

\section{Uvod}

Sukob Jugoslavije i Saveza Sovjetskih Socijalističkih Republika (SSSR), 1948. godine snažno je utjecao na zemlju u gotovo svakom njenom aspektu. Temeljite promjene dogodile su se u oblasti ideologije, diplomacije, ekonomije, državnog i partijskog uređenja, itd. Posebno je bila zahvaćena i sama Partija, jer je sukob provocirao novi val unutarpartijskih sukoba i frakcija koji se principijelno ticao odnosa prema Rezoluciji Informbiroa, premda često to nije bio isključivo slučaj. Tako je u dramatičnoj atmosferi raskola partijski vrh potakao hapšenja stvarnih i navodnih ibeovaca, od kojih je 15.737 internirano u logore, najviše na Goli otok, gdje su bili podvrgnuti sistemskim mučenjima u cilju tzv. ,političkog

\footnotetext{
${ }^{1}$ Hrvatski državni arhiv (HDA), fond 1561, Republički sekretarijat unutrašnjih poslova Socijalističke Republike Hrvatske, Služba državne sigurnosti, (RSUP SRH SDS), Informbiro, Dosje Stanko Opačić (322 926).
} 
preodgoja“" ${ }^{2}$ Tisuće drugih bili su zahvaćeni drugim oblicima kažnjavanja, najčešće nekim oblicima partijskih kazni ili udbaških evidentiranja. Dugo su, sve do 1980-ih godina, ibeovci od Partije prikazivani kao „staljinisti“ čime se zamagljivala raznolikost ibeovske opozicije, kao i raznolikost motiva zašto je netko od strane Udbe etiketiran kao ibeovac i da li je to on uopće i bio. ${ }^{3}$ Naknadnom analizom vidimo da je za Udbu biti ibeovac značilo podržavati Rezoluciju, biti protivnik kolektivizacije, podržavati stranu Sjeverne Koreje u Korejskom ratu, slušati radio stanice Istočnog bloka, itd.

Svakako da slučaj hapšenja tri ministra (srpske nacionalnosti) Rade Žigića, Duška Brkića i Stanka Opačića u vladi Narodne republike (NR) Hrvatske 1950. godine spada u jedan od važnijih događaja hapšenja visoko pozicioniranih funkcionera Komunističke partije Jugoslavije (KPJ) pod optužbom za podršku Rezoluciji Informbiroa. ${ }^{4}$ Ovaj slučaj posebno je interesantan jer je bila riječ o tri vrlo istaknuta političara sa područja NR Hrvatske, sa važnim ulogama tijekom Narodnooslobodilačke borbe (NOB), koji su kao takvi imali poseban značaj i ugled u Partiji, ali i na lokalnoj razini, posebno u osjetljivoj poratnoj atmosferi, koja je uslijedila nakon krvavog rata. Iako se ovaj rad bavi Opačićevom političkom sudbinom u užem smislu, njegov politički pad ipak je vezan uz sudbine Žigića i Brkića. Čini se da postoji konsenzus među historičarima da se uzroke njihovog pada treba tražiti u izuzetno napregnutim poratnim odnosima te prilično traumatičnoj dinamici ranog jugoslavenskog staljinizma, ali i u njihovim političkim ili ideološkim odrednicama, kao i političkoj kulturi, mentalitetu i raznim lokalnim specifičnostima. ${ }^{5}$ Konkretno, poslijeratna teška ekonomska situa-

${ }^{2}$ Martin Previšić, Povijest Golog otoka (Zagreb: Fraktura, 2019), 462.

${ }^{3}$ Za više vidi: Isto, $63-86$.

${ }^{4}$ Naravno, ovo nije bio jedini takav slučaj. Tijekom sukoba sa Staljinom hapšeni su i brojni drugi ministri u saveznim i republičkim vladama, poput Save Zlatića, ministra u vladi FNRJ, Vuke Tmušića i Nike Pavića (ministri u Crnoj Gori), i drugih. Isto, 423-447.

${ }^{5}$ Tema „ministarske trojke“, iz različitih aspekata i pristupa, obrađivana je na više mjesta u dosadašnjoj historiografiji. Vidi: Ivo Banac, With Stalin against Tito (Ithaca and London: Cornell University Press, 1988), 181-188; Darko Bekić, Jugoslavija u hladnom ratu (Zagreb: Globus, 1988); Драгомир Бонџић, „Кордун у социјалистичкој Југославији“, у: Кордун - Од војне границе до Републике Српске Крајине, ур. Момчило Павловић (Београд: Институт за савремену историју, 2018), 385-389; Drago Roksandić, Srbi u Hrvatskoj (Zagreb: Vjesnik, 1991), 147-150; Berislav Jandrić, Hrvatska pod crvenom zvijezdom (Zagreb: Srednja Europa, 2005), 270-275; M. Previšić, n. d., 127, 161-162, 215, 520; Момчило Митровић, „Три ибеовца у Хрватској 1950. године“, Токови, бр. 1-4, (1998), 179-191; Милан Весовић, „Станко Опачић Ћаница: путеви и беспућа кордунашког сељака“, Историја 20. века, бр. 1, (1996), 153-162; Vladimir Dedijer, Novi prilozi za biografiju Josipa Broza Tita, Treći tom (Beograd: Rad, 1984), 459. Knjiga Čedomira Višnjića Partizansko ljetovanje (Zagreb: Prosvjeta, 2003), pokušava dati pogled na uzroke pada „ministarske trojke“. Višnjićeva knjiga je fundirana na arhivskim izvorima, ali bez upotrebe znanstvenog aparata, što nešto govori o njezinim ciljevima pa i svrsi. Iako autor traži uzroke njihova pada, teško se oteti dojmu da iako suštinski Partizansko ljetovanje funkcionira kao historiografska studija, ona je imala (ili ima) dnevnopolitičku svrhu, prikladniju Višnjićevoj potrazi za trenutnom političkom logikom, nego za nekom povijesnom istinom. Uz vrlo selektivan izbor dokumenata, ono što je Višnjić uspio bar malo ocrtati jest mentalitet „ministarske trojke“ i onih koje su oni predstavljali. Godine 1989. u izdanju beogradske Litere izašla su Opačićeva sjećanja: Станко Опачић Ћаница, Србин у Хрват- 
cija u Jugoslaviji, u ovom slučaju u „ustaničkim“ dijelovima Hrvatske, traumatična iskustva rata, a potom i radikalne partijske mjere prisilnog otkupa, a od početka 1949. godine i agresivne kolektivizacije, naišle su na velik otpor i revolt stanovništva, prilikom čega je nezadovoljstvo imalo razne oblike manifestacije. Palila se ljetina, zazivalo povratak kralja, dizale bune (npr. Cazinska buna), a nakon 1948. godine neki su vjerovali da je podrška Staljinu i Rezoluciji Informbiroa prikladan oblik otpora. Treba odmah naglasiti da Žigić, Brkić i Opačić nisu činili organiziranu grupu, kako možda termin „ministarska trojka“ sugerira, te, prema onome što nam dokumenti kazuju, nisu politički koordinirali svoje postupe sve do pred njihova hapšenja u septembru 1950. godine. Ono što ih je vezalo, a to je posebno slučaj kod Opačića, jeste da su sva trojica imala snažnu lokalnu bazu (Žigić u Lici, Brkić u zapadnoj Slavoniji, te Opačić na Kordunu), izgrađenu u ratu, kao i poseban emotivan lokalistički pristup politici. Zbog fokusa ovog rada nema potrebe (niti prostora) pojedinačno analizirati sva tri slučaja, ali svakako da je onaj Rade Žigića bio najvažniji te svojevrsni okidač pada i Brkića i Opačića. On je i prvi došao kao predmet partijske debate.

$\mathrm{Na}$ trodnevnoj sjednici Politbiroa Centralnog komiteta (CK) Komunističke partije Hrvatske (KPH) od 26. do 29. augusta 1950. vrh komunista Hrvatske „raspravljao“ je „slučaj“ Rade Žigića, odnosno kako stoji „razmimoilaženje druga Žigića sa linijom CK KPJ“. ${ }^{6}$ Dolazak Edvarda Kardelja i Aleksandra Rankovića na sjednicu govori o važnosti ovog slučaja u cjelini. Žigić je (partijski) optužen da je kominformovac (ibeovac), da se ne slaže sa osobnim životom nekih partijskih drugova, da kritizira propagandu protiv Kominforma (Informbiroa), da iz nezadovoljstva trenutnim stanjem u državi te raznim mjerama koje vlast koristi želi podnijeti ostavku na sve položaje, itd. Ukratko, Žigić je u svojim izlaganjima na sjednici naglašavao da nije simpatizer Informbiroa; prilično otvoreno je govorio o tome kako je on vidio neke partijske drugove te je oštro ocjenjivao njihov karakter: („Iveković ${ }^{7}$ je lažov, sve je izmislio, to je naduven čovjek, nikada ga nisam cijenio (...) I Pajo ${ }^{8}$ laže (...) Pajo je senilan čovjek i pričao je o situaciji po svijetu, napadao Marksa i Lenjina da nisu imali pravo..."); nije se slagao za izrazito napadnim antisovjetskim pisanjem u tadašnjoj štampi; posebno je negodovao oko izrazito loše ekonomske situacije i politike prema „ustaničkim krajevima“, itd. ${ }^{9}$ Može se pretpostaviti tijek daljnje debate, u kojoj su u velikoj većini, osim prisutnoga Duška Brkića (koji će se i sam uskoro naći u sličnoj poziciji), ostali sudionici u uobičajenom „monolitnom“ politbirovskom nastupu oštro kritizirali Žigića, svako iz svog kuta i motiva. Sigurno da

ској - Казивања кордунашког сељака, ратника, министра, осуђеника... (Београд: Литера, 1989). U ovoj knjizi, koju je uredio Milan Vesović, Opačić u svojim zapisima daje pogled uglavnom na razdoblje rata, ali i kraće osvrte na kasnije događaje.

${ }^{6}$ Branislava Vojnović, prir., Zapisnici Politbiroa Centralnog komiteta Komunističke partije Hrvatske, Sv. 2 (Zagreb: HDA, 2006), 445.

${ }^{7}$ Mladen Iveković (1903-1970). Član KPJ prije rata, član AVNOJ-a i ZAVNOH-a, te ministar u Vladi NR Hrvatske. Nakon rata osim ministarske obnašao i funkcije u diplomaciji.

${ }^{8}$ Pavle Gregorić - Brzi, Pajo (1892-1983).

${ }^{9}$ B. Vojnović, $n$. d., 446-449. 
Žigićev otvoren i direktan kritički ton nije pomogao njegovoj poziciji. U svom govoru Aleksandar Ranković zapečatio je sudbinu Rade Žigića: „Jučerašnje istupanje Žigića nije pokazalo ni trunke samokritičnosti, a on to nije ni mogao pokazati jer se izdvojio od Partije, izradio svoju liniju i jer stoji na liniji Kominforma (...) Po njemu niti jedan od drugova ne ispunjava najosnovnije uslove za članstvo u Politbirou. Izvlači jednog po jednog da bi mu srušio autoritet u narodu. To je taktika Kominforma. “10 Zaključak sjednice je bio jasan: Žigića kao kominformovca treba suspendirati, što je bio samo eufemizam za eliminaciju iz Partije (malo kasnije je i formalno izbačen), a vidjeti će se i za daljnje partijske sankcije. Slučaj Žigića je važan jer je otvorio put za pad Brkića i Opačića. Duško Brkić, jedini član Politbiroa KPH koji se otvoreno solidarizirao i koji je branio Žigića, doveden je pred ,partijski sud“ 3. septembra 1950. te je zaključeno da je ,reagirao kao zatucani šovinista“, „Na sjednici na kojoj se raspravljalo o Radi Žigiću Duško se držao kolebljivo“", te da je simpatizer Kominforma. ${ }^{11} \mathrm{Za}$ ključeno je da ga se kao i Žigića suspendira iz Partije. U samo nekoliko dana Žigić i Brkić su nakon otvorenog negodovanja nizom političkih i ekonomskih mjera Partije - koje su sezale od nedovoljno brzog oporavka ustaničkih krajeva, raznih jezičnih i kulturnih (nacionalnih) pitanja, pa do vrlo osjetljivog pitanja odnosa prema SSSR-u - faktički izbačeni iz KPJ te će uskoro biti prepušteni Udbi. Uskoro će im se pridružiti i Stanko Opačić Ćanica.

\section{Ćanica postaje treći}

Kao što je već rečeno, „ministarska trojka“ nije bila koherentna grupa koja je djelovala sinkronizirano, posebno ne u razdoblju od 1945. do 1950. godine. Ono što je spojilo Žigića, Brkića i Opačića, posebice u danima njihova političkog kraja, jeste već spomenuto nezadovoljstvo partijskom politikom. ${ }^{12}$ Opačić je tih dana bio upućen u situaciju. Dana 3. septembra 1950. pozvan je u CK u Zagreb gdje mu je rečeno trenutno stanje oko Žigića i Brkića. Kada je čuo za razloge partijske istrage rekao je prisutnima (Zvonko Brkić, Nikola Sekulić, Mile Počuča), da „sam i ja dosta ovih stvari ranije iznosio“. ${ }^{13}$ Već sljedeći dan sastao se u pros-

\footnotetext{
${ }^{10}$ Isto, 472.

${ }^{11}$ Isto, 492.

${ }^{12}$ Nakon što je bio uhapšen, Opačić je u istrazi Udbi otkrio detalje svoga odnosa sa Žigićem i Brkićem što baca svijetlo na njihovu pretpovijest i povezanost. Opačić je tvrdio da sa Žigićem nije imao prisniji odnos osim onoga profesionalnog: „Međutim sa Radom Žigićem nijesam imao nikakav bliži kontakt. Jedino što smo se vidjeli nekada na pojedinim konferencijama ili sjednicama Vlade (...) Mimo službenih kontakata sa Žigićem nijesam imao nikakovih prijateljskih veza. Kako mi ranije Žigić nije prilazio ja sam imao dojam da on na mene gleda sa visoka, kao na čovjeka manje vrijednoga.“ Opačić je za svoj odnos sa Duškom Brkićem dao malo drugačiju sliku: „Sa Duškom Brkićem ja sam bio u dobrim prijateljskim odnosima već dugo vremena, još od prije oslobođenja. Sa njime nijesam imao češći kontakt sve dok on nije postao podpredsjednik vlade od kada sam po službenoj dužnosti često sa njime dolazio u dodir. Naše medjusobne kućne posjete bile su vrlo rijetke i koliko se sjećam bio sam kod njega od oslobođenja svega četiri pet puta." HDA, 1561, RSUP SRH SDS, Dosje Stanko Opačić (322 926), 27.

${ }^{13}$ Isto, 5 .
} 
torijama Srpskog kulturnog društva „Prosvjeta“ sa Žigićem i Brkićem koji su mu rekli da više nisu ministri te su mu naveli razloge zbog koji su faktički izbačeni i Partije. ${ }^{14}$ Prema zapisniku istrage koja je kasnije vođena nad Opačićem, njega je na sastanku sa Žigićem i Brkićem revoltirala informacija koju su mu njih dvojica dali, toliko da je i on odlučio dati ostavku. Naime, rekli su mu da ga je Zvonko Brkić nazvao četnikom, a Mile Počuča - šovinistom. ${ }^{15}$ Sljedećeg dana, 5. septembra, Opačić je napisao ostavku na svoje pozicije i predao ju sekretaru Predsjedništva Vlade NR Hrvatske Odrljenu. Nakon toga je saznao da je „Prosvjeta“ donijela odluku da se Žigiću i Brkiću zabranjuje ulazak u prostorije društva jer su ibeovci. ${ }^{16}$ Opačić se malo kasnije sastao sa Žigićem i Brkićem, kako bi prokomentirali njihovo izbacivanje iz „Prosvjete“ i Opačićevu ostavku.

Na kraju dana Opačić je dobio poziv da se javi u CK Vladimiru Bakariću u 19 sati. Prema Opačićevom iskazu, Bakarić se složio sa razlozima za ostavku: „(...) te da osim nekoliko mojih ocjena koje sam dao u ostavci, ostale stvari stoje i da nijesu riješene. “17 Prema Opačićevom svjedočanstvu, Bakarić ga je podržao u nekim kritikama ali mu je sugerirao da se problemi ne mogu rješavati ,,preko Informbiroa“. ${ }^{18}$ Očito je da Bakarić pokušavao Opačića odvojiti od Žigića i Brkića, kada mu je prepričao zaključke sjednice PB CK KPH o njima (,naglasivši da su oni na liniji Informbiroa“). Uvjeravajući Opačića da se nagomilani problemi rješavaju postepeno, Bakarić je odložio Opačićevu ostavku (,ne smatra da sam podnio ostavku“) te mu dao vremena za razmišljanje. ${ }^{19}$ Opačić se sada našao na brisanom prostoru, jer s jedne strane mu je bilo prilično jasno da mu Bakarić daje određenu priliku za politički opstanak (uz ,dobru volju“ za rješavanje raznih gorućih pitanja), a s druge strane bio je vezan uvjerenjem i očito emocijama sa Žigićem i Brkićem. Kolebanje nije dugo trajalo jer je već sljedeći dan, 6. septembra, ponovno razgovarao sa Žigićem i Brkićem, koji su ga uvjerili da je Bakarićeva „,dobra volja“ prazna demagogija. Sljedeći dan (7. septembar), Opačić je otišao u svoje ministarstvo te predao svoju ostavku, što mu je zapečatilo sudbinu.

Stvorila se ,ministarska trojka“, vrijeme je ubrzano teklo, i sva trojica su bila pred hapšenjem. Nakon svega niti oko Opačića više nije bilo dileme i njegov „slučaj" trebao se formalizirati, pa je 8. septembra formirana komisija CK KPH u sastavu Mika Špiljak, Perica Dotez i Mane Trbojević koja je trebala „utvrditi““ Opačićev stav prema ibeovcima Žigiću i Brkiću. Sudeći po šturom zapisniku, Opačić se rezolutno postavio prema pitanjima komisije; na pitanje zašto se sastajao sa Žigićem i Brkićem, Opačić je odgovorio: „Ja sam išao k njima, to mi ne može nitko zabraniti da idem, jer sam htio čuti šta oni kažu. " ${ }^{\text {‘20 }}$ Osim toga u zapisniku stoji da je Opačić podržavao stavove Žigića i Brkića ne zato jer su, kako je to Partija okarakterizirala, kominformovski, već zato jer su ukazivali na niz nepravilno-

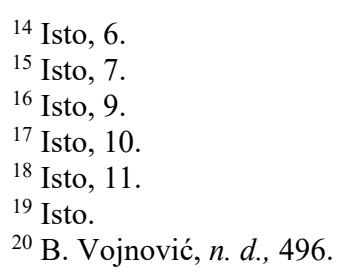


sti koje se nisu rješavale. Na kraju zapisnika stoji Opačićeva izjava koja upućuje na njegovu realnu procjenu situacije ali i poznavanje partijske tehnologije rada: „Ja mogu govoriti šta hoću, a zaključak će biti takav, kakav vama bude potreban“. ${ }^{21}$ Komisija je donijela predvidljiv zaključak da Opačić djeluje zajedno sa Žigićem i Brkićem te da predlaže CK da se prema njemu postupi na jednak način kao prema prethodnoj dvojici. Isti dan sastao se PB CK KPH koji je potvrdio zaključke komisije i de facto razriješio Opačića svih dužnosti. ${ }^{22}$ Nakon toga stvari su išle u jednom smjeru. Dana 10. septembra 1950., Opačić je izašao iz kuće da kupi novine kada je uhapšen. Isti dan uhapšeni su i Rade Žigić i Duško Brkić. ${ }^{23}$

\section{Istraga nad Opačićem i kažnjavanje}

Ubrzo su partijske organizacije u ,ustaničkim krajevima“ obaviještene o partijskim sankcijama prema Žigiću i Brkiću, a nakon toga i Opačiću. Na Kordunu, uglavnom, u tom času nije bilo veće reakcije iako su npr. u kotaru Slunj zabilježeni istupi šovinističkih sadržaja koji su, sukladno razini političke kulture i ,zategnutih“ međunacionalnih odnosa, tumačili smjenu Opačića u tom ključu. Tako je zabilježeno da su neki pojedinci izjavili: „Nema nama [Srbima op. M. P.] mjesta u Hrvatskoj sada imade samo dva Srbina u ministarstvu pa će i to uskoro za njima. ${ }^{\text {24 }}$ Uglavnom, sukladno modelu partijske discipline i hijerarhije niži organi su prihvaćali faktičko stanje.

Nakon gotovo dva tjedna pritvora (hapšenja) počela je formalna istraga nad Opačićem. ${ }^{25} \mathrm{U}$ vremenu jugoslavenskog staljinizma, a posebno u periodu sukoba Tito-Staljin, hapšenje i posljedična istraga (od strane Udbe) značila je i stvarnu krivnju, a posebno u slučaju visoko pozicioniranih osoba kakav je bio i Opačić. ${ }^{26}$ Glavni cilj istrage, u njegovom slučaju, bilo je sakupljanje što većeg materijala i inkriminacija koje bi se kasnije mogle eventualno koristiti kao materijal na suđenju, te otkrivanje ponekih detalja ili pojedinaca koji su eventualno do tog trena promakli Udbi. Tajnu policiju su u slučaju Opačića zanimali svi detalji vezani uz odnose sa Žigićem i Brkićem; i to posebno unazad nekoliko mjeseci prije hapšenja. Posebno detaljno, mjeseci august i septembar 1950. godine. Ispitivani su i razgovori i odnosi sa drugim osobama poput Bogoljuba Rapajića, a ispitivana je i Opačićeva supruga Dragica, koja nije bila upućena u politiku. ${ }^{27}$ Tako

21 Isto.

22 Isto, 494.

${ }^{23}$ HDA, 1561, RSUP SRH SDS, Dosje Stanko Opačić (322 926), 15; HDA, 1561, RSUP SRH SDS, Informbiro, „U prilogu vam dostavljamo knjigu sa spiskom i osnovnim podacima za sve kažnjenike DKR i osudjenike po IB-u, koji su evidentirani u VIII odelenju Udbe FNRJ (...)“, (Dalje: „Popis“).

24 Д. Бонџић, „Кордун у социјалистичкој Југославији...“, 387.

${ }^{25} \mathrm{Za}$ Opačićev prikaz istrage vidi: С. Опачић Ћаница, Србин у Хрватској..., 92-94.

${ }^{26} \mathrm{Za}$ više o Udbinom procesu i metodologiji istrage u vrijeme sukoba Tito-Staljin vidi: M. Previšić, $n$. d., 99-139.

${ }^{27}$ Dragica Opačić je bila kućanica bez većih političkih aspiracija i interesa. Uzgred govoreći, za vrijeme rata radila je u partizanskoj bolnici na Petrovoj gori, a od 1942. godine pri AFŽ-u na području Slunja, Plaškog i Vojnića. Iz zapisnika njenog isljeđivanja vidljivo je da je uglavnom prepričavala kućne razgovore sa svojim mužem oko razloga ostavke ili reakcija Žigića i Brkića 
su Udbu zanimali svi sastanci i sadržaji razgovora vođeni između njih trojice u tom vremenu, što su Žigić i Brkić govorili o Informbirou, mjerama otkupa, jugoslavenskom stavu prema SSSR-u, pisanju štampe, ratu u Koreji, itd. Više-manje sve. U zapisniku se može naći i nekoliko duhovitih Opačićevih opaski koje malo ocrtavaju njegov karakter i mentalitet. Za sastanke $C K$, na primjer, rekao je da izgledaju na sastanke Antifašističkog fronta žena (AFŽ) ${ }^{28}$ Jednom prilikom, tijekom dana kada su podnosili ostavke, Žigićeva žena je upitala Opačića kako je, na što je ovaj odgovorio: „Ko rashodovani ministar“6 29

Udba je ozbiljno pripremala materijal za eventualno suđenje. Prva runda istrage počela je 23. septembra 1950. i trajala do 4. decembra 1950. i ticala se gore navedenih detalja. Nakon više od šest mjeseci stanke počela je nova serija istrage (15. juna 1951.), ali ovaj puta Opačića se konfrontiralo sa iskazima prikupljenim od drugih ljudi, koji su služili kao optužni materijal. U istragama su mu ,predočeni“ iskazi koji su ga imali inkriminirati poput onoga gdje je Đuri Ljubotnici navodno rekao da se ,slizao u Zagrebu s Hrvatima-ustašama, koji hoće da likvidiraju ćirilicu u srpskim selima“. ${ }^{30}$ Dmitar Trbović dao je iskaz u kojem se teretilo Opačića da je rekao prilikom debate o muzeju u Vojniću da su „frankovci uhvatili maha“ što ga je trebalo prikazati kao šovinista. ${ }^{31}$ Osim toga bile su predočivane izjave gdje je Opačić izražavao podršku SSSR-u, kritizirao mjere otkupa, pitanja upotrebe ćirilice, itd. Više-manje Opačić je sve negirao. Ionako više nije imalo smisla, što je Opačić vjerojatno znao. Istraga je završena isti dan, te je zaključeno da je Opačić ,širio neprijateljsku i šovinističku propagandu i da je pristupio informbiroovskoj grupi, koju su organizirali Rade Žigić i Duško Brkić sa ciljem da se putem nasilja ugrozi postojeće Ustavno uređenje u FNRJ.“32 Opačić je na zaključak izjavio da je „U svom radu nailazio na razne poteškoće, ali uslijed svoje naglosti i temperamentnosti nekada bi na pojedine stvari u dodiru sa pojedinim licima možda i nepravilno reagirao, ali kod ni jedne stvari nisam imao zlu namjeru (...) Što se tiče mog istupanja zajedno sa Žigićem i Brkića tu sam stvar detaljno iznio u zapisniku. Napominjem ponovno da se oni predamnom nijesu izjasnili kao infombiroovci, već su pojedine stvari koje su mene smetale znali iskoristi da me vežu uz sebe. ${ }^{633}$

kada su bili gosti u kući Opačićevih. Pitana je tko su bili gosti koji su dolazili u njihov stan u vrijeme ostavke, tko je zvao na telefon u to vrijeme, ali i čitav niz potpuno nevažnih i pomalo smiješnih pitanja poput toga gdje se Opačić hranio 8. i 9. septembra 1950. dok mu je žena bila u Tušiloviću. Opačić općenito, sudeći po zapisniku, nije ženu upućivao u bilo kakve detalje svog političkog rada. HDA, 1561, RSUP SRH SDS, Dosje Stanko Opačić (322 926), 45/C64/C. Sličnu seriju ispitivanja prošla je i supruga Rade Žigića, Amalija Žigić. Vidi: HDA, 1561, RSUP SRH SDS, Dosje Rade Žigić (301 866).

${ }^{28}$ HDA, 1561, RSUP SRH SDS, Dosje Stanko Opačić (322 926), 34.

${ }^{29}$ Isto, 14.

${ }^{30}$ Isto, 37.

${ }^{31}$ Isto.

${ }^{32}$ Isto, 40.

${ }^{33}$ Zaključak u istrazi donesen je na osnovu svjedočenja ljudi iz Opačićeve okoline, ali je to učinjeno iz formalnih razloga, u svrhu pripreme suđenja. „Svjedoci“ čije su izjave bile korištene kao inkriminirajući materijal u Udbinoj istrazi protiv Opačića bili su: Dmitar Trbović, Đuro Vujić, Đuro Ljubotina, 
Istraga je bila završena, a u to vrijeme Opačić je već bio demoniziran u svom kraju na partijskim sastancima i mitinzima kao „,malodušnik“, ,,dezerter“ i „,izdajnik“ ${ }^{34}$ Skoro dva mjeseca nakon hapšenja, Opačićeva kćerka, đak Visoke novinarske škole u Beogradu, vjerojatno je bila prisiljena dati izjavu dana 26. novembra 1950. protiv svoga oca: „Ovih dana iz Rezolucije CK KP Hrvatske saznala sam da moj otac potpomaže svojim postupcima tu rušilačku politiku prema mojoj zemlji (...) Sve do tog dana kada je on bio član KPJ i dokle sam vjerovala da on ispravno radi naši putevi su se poklapali. Od sada to više nije moguće. Ni autoritet SKP(b) i Staljina, a još manje autoritet mojeg oca nisu i ne mogu mene da učine izdajnikom ove zemlje (...) Moj životni put je put Komunističke Partije Jugoslavije na čelu sa njenim Centralnim komitetom i drugom Titom i pod njihovim rukovodstvom spremna sam na sve napore pa ustreba i na smrt. ${ }^{\text {"35 }}$ Ovo je bio još jedan primjer staljinizma onog doba. ${ }^{36}$

I sam Tito je prilikom posjete Kordunu izjavio da „unutrašnji neprijatelji koji poput Ćanice Opačića pokušavaju da seju razdor među narode i razbijaju državu i narodno jedinstvo nisu dostojni da budu građani nove Jugoslavije jer više vole ono tuđe, što nisu nikad vidjeli, nego svoju zemlju na kojoj su živjeli njihovi djedovi i pradjedovi." ${ }^{\text {37 }}$ U samo nekoliko godina Opačić je, bar što se Partije tiče, prošao put od junaka do izdajnika.

Vladimir Babić, Josipa Mačešić, Gojka Jerinić, Mile Kunić, Miloš Velimirović i Sava Vukdragović, uz naravno svjedočenja Žigića i Brkića. Isto, 40-41. Osim toga, skupljana su svjedočenja protiv Opačića i na Golom otoku. Takav je primjer ,nadopuna zapisnika“ Radojice Petrovića gdje je Opačić optužen za pravljenje nepotrebnih troškova Ministarstvu drvne industrije. Isto, 102/a. U dokumentima koji se tiču istrage Stanka Opačića nalazimo brojne zapise i svjedočenja koja u zaključcima istrage nisu razmatrana kao relevantna, a i njihov sadržaj je često izvan političkog konteksta. Tako je Ljubica Miljenović iz kotara Vojnić dala izjavu gdje je Opačić rekao: „U mjesecu junu 1950. godine moja kćerka Stana svršila je srednju-tehničku školu, te sam otišla kod Ćanice kući i zamolila ga da mi nastoji ishoditi kćerki namještenje u Zagrebu, kako bi lakše živjele. On mi je tom prilikom rekao da je Zagreb najpokvareniji grad, te da je bolja da moja mala otidje raditi negdje u popaljenu Liku ili Kordun, jer će joj tamo biti bolje." Isto, 130/C. Ispitivan je bio Opačićev šofer u ministarstvu, Stevo Savudrić, koji je samo opisivao rute gdje je vozio Opačića i njegove drugove. Jednom je prevozio ministarsku trojku koja je bila pred hapšenjem i kada je izašao Žigić mu je dobacio: „Ako te uhapse, ja nisam kriv." Autoironija u kombinaciji sa sarkazmom. Osim toga, kao i drugi, Savudrić je naveo nekoliko primjera gdje je Opačić na terenu izjavio da je otkup pljačka, te da je nužno više parola na ćirilici na zidu u selu Cemernici, kotar Vrginmost. Isto, 25/C-28/C. Navedeni primjeri su samo neki od više njih koje je sakupila Udba (10-15 izjava različitih osoba), gdje se Opačić na razne načine inkriminira. Dovodio se čak i ratni put u pitanje, jer ibeovci nisu mogli biti dobri borci. Stanoviti pukovnik Ilija Pavlović opisivao je svoje utiske o Radi Žigiću tijekom rata, koji su bili loši: „Tada sam zapazio da se Žigić jako plaši bombardovanja, jer je bio jako uznemiren i nervozan, te je zabranjivao čak i glasniji razgovor. Posle je Žigić prebačen u GSH [Glavni štab Hrvatske - op. M. P.], a kasnije i Žigić za komesara GSH. Tu sam Žigića još bolje upoznao i stvorio svoje mišljenje o njemu. Da je karaktera kolebljivog, naravi veoma plahovite, slavoljubiv, prek i nepromišljen (...) Vojnu nauku nije poznavao, pa čak nije niti znao da čita kartu sekciju. Isto, 79/C.

34 Д. Бонџић, „Кордун у социјалистичкој Југославији...“, 387.

${ }^{35}$ M. Previšić, $n$. d., 127.

${ }^{36} \mathrm{Za}$ više o radu i funkcioniranju Novinarske i diplomatske visoke škole vidi: Драгомир Бонџић, прир., Новинарска и дипломатска висока школа 1948-1953 (Београд: Институт за савремену историју, 2013).

${ }^{37}$ Д. Бонџић, „Кордун у социјалистичкој Југославији...“, 387-388. 
Istraga je bila gotova i Udba je pronašla, kao što se vidi iz njihovih materijala o Stanku Opačiću, velik broj svjedočanstava koji su ga, sukladno od Partije određenoj sudbini, inkriminirali i pripremili za sud. Treba reći da za razliku od poslijeratnih suđenja kolaborantima i raznim drugim ,neprijateljima države“ Partija je nastajala izbjegavati velika suđenja ibeovcima, iako je takve intencije imala. Iznimke su velika suđenja preživjelima iz ,generalske zavjere“ (Dapčević i Petričević) ili suđenje „Četrnaestorici“ tj. Proces cestograditeljima. ${ }^{38}$ Od suđenja Andriji Hebrangu se odustalo, premda postoje jasne indicije da se ono spremalo. ${ }^{39} \mathrm{Za}$ razliku od suđenja kolaborantima, Partija nije mogla predvidjeti učinak suđenja partijskim prvacima poput Andrije Hebranga pa se od takvih suđenja odustalo. Sličan slučaj je sa pripremljenim suđenjem ,ministarskoj trojci“ Žigiću, Brkiću i Opačiću. Naime, kao što se moglo vidjeti iz detaljnog procesa istrage i velikog prikupljenog ,dokaznog“ materijala, Partija je namjeravala organizirati suđenje trojci, štoviše pripremljena je i optužnica. Datirano dana 20. juna 1951. godine, Javno tužilaštvo za Grad Zagreb pripremilo je optužnicu (B 329/51) na osnovu člana 35. točka 5. protiv prvooptuženog Rade Žigića, drugooptuženog Duška Brkića i trećeoptuženog Stanka Opačića. ${ }^{40}$ Treba zamijetiti kako je redoslijed optuženih ujedno i neka vrsta hijerarhije krivnje te značaja optuženih ali i kronološki slijed stvaranja ,grupe“. Opačić je kao trećeoptuženi terećen za povezivanje sa Žigićem i Brkićem, te da je pod njihovim utjecajem (sic!) prišao neprijateljskoj ibeovskoj grupi te širio ibeovsku i neprijateljsku propagandu. ${ }^{41} \mathrm{U}$ jako dugačkoj formi u optužnici su izneseni dokazni materijali sastavljeni od svjedočanstava iz istrage koja su imala potvrditi inkriminacije. Krajnji cilj trećeoptuženog Opačića, prema optužnici, bio je: ,....) pozivao na nasilno obaranje postojećeg državnog rukovodstva, vršio agitaciju kojom se išlo za tim da se izazove i raspali nacionalna mržnja, te je pristupio udruženju koje je imalo za svrhu da se putem nasilja ugrozi i obori postojeće državno uređenje Federativne Narodne Republike Jugoslavije, njena vanjska sigurnost i tekovine oslobodilačkog rata."42 Javni tužilac Mato Zaninović predložio je suđenje tj. raspravu pred Okružnim sudom gdje bi svjedoci (Čuić, Lukić, Babić, Uzelac, Ljubotina i drugi), iznosili svoje argumente protiv trojke.

Od suđenja se, međutim, odustalo. Vjerojatno zbog straha da suđenje „Svojim“ članovima Partije, visokopozicioniranim ministrima i partizanskim veteranima sa velikim ratnim pedigreom ne prouzroči kontraefekt; i nacionalni i ideološki. Zato se kao i što je slučaj sa većinom ibeovaca (10.999) pristupilo kažnjavanju administrativnom mjerom društveno korisnog rada. ${ }^{43}$ Riječ je o drugačijoj formi, ali sličnom sadržaju ili bolje rečeno epilogu. Odustalo se i od suđenja Opačiću, zajedno sa Žigićem i Brkićem, te ga se kao kaznilo društveno korisnim radom. Dana 21. oktobra Komisija za prekršaje, III. Rajona grada Za-

\footnotetext{
${ }^{38}$ Za više o suđenjima ibevcima vidi: M. Previšić, $n$. d., 143-165.

${ }^{39}$ Isto, 160. Vidi još: Mile Milatović, Slučaj Andrije Hebranga (Beograd: Kultura, 1952); Nada Kisić Kolanović, Hebrang iluzije i otrežnjenja (Zagreb: Institut za suvremenu povijest, 1996), 204-225.

${ }^{40}$ HDA, 1561, RSUP SRH SDS, Dosje Stanko Opačić (322 926), 42.

${ }^{41}$ Isto, 50.

${ }^{42}$ Isto, 51.

${ }^{43}$ M. Previšić, $n$. d., 144.
} 
greba, donijela je „Rješenje“ kojim ga se „u cilju prevaspitavanja upućuje na društveno korisni rad u trajanju 24 mjeseca“". 44

\section{Stanko Opačić na Golom otoku}

Opačić je krenuo na društveno korisni rad. Sudeći prema dijelu dosjea iz logora, stigao je na Goli otok sa IX. grupom Udbe Hrvatske 18. oktobra 1951. godine. ${ }^{45}$ Postoji određeni nesklad oko utvrđivanja činjenice da li je trojka došla zajedno na Goli otok ili odvojeno. Logoraš Golog otoka Mihailo Simić prisjeća se da su Opačić i Brkić zajedno došli u logor te da u špaliru ${ }^{46}$ nisu prebijeni već samo pljuvani. ${ }^{47}$ Logoraš Radovan Hrast prisjeća se da je Rade Žigić sam došao na Goli otok te da je samo pljuvan: „I ide Žigić kroz stroj, ponosno kao general, a ljudi ga pljuju. “48 Postoji verzija prema kojoj je Opačić stigao sam, a nakon njega su u logor došli Žigić i Brkić. ${ }^{49}$ Sigurna činjenica je da su sva trojica nakon što su im izrečene kazne dospjeli u logor. Interesantno pitanje je zašto nisu internirani u tzv. „Petrovu rupu“, specijalni logor u logoru na Golom otoku u koji je Udba zatočila većinom važne ibeovce, mahom generale, ministre, visoke partijske funkcionare, članove predratnih vrhuški KPJ, legendarne borce NOBa, komuniste sa dugim stažom u Moskvi, itd. ${ }^{50}$ Kao ministri i lideri ustanaka u svojim sredinama svakako su se „kvalificirali“ za internaciju u „Petrovu rupu“, te su se tamo trebali naći ili po funkciji ministara (poput Zlatića, Tmušića, Pavića) ili po svojoj „ratnoj stazi“ (npr. Dapčević, Petričević, Žarić, Poljanac, itd.).

Opačić je kao i svi morao proći „proces političkog preodgoja“ na Golom otoku, što je podrazumijevalo prolazak kroz nekoliko stanica tog složenog procesa. Suština se svodila na sudjelovanje u raznim, od strane Udbe, orkestriranim ritualima nasilja i denuncijacija. Logoraš se morao konstantno dokazivati svojim radom, nasiljem prema drugim logorašima, te denuncijacijama stvarnih ili navodnih ibeovaca na Golom otoku ili na kopnu. Možda ključni dokument tog procesa jeste „dopuna zapisnika“. Osnovna ideja Udbe bila je da logoraši skrivaju druge ibeovce na slobodi i da nisu sve rekli u istrazi (zapisniku) na ko-

\footnotetext{
${ }^{44}$ HDA, 1561, RSUP SRH SDS, Dosje Stanko Opačić (322 926), 58.

${ }^{45}$ Premda se ne slažu datumi, jer je „Rješenje“ datirano kasnije od odlaska na Goli otok, vjerojatno je riječ o birokratskom problemu. Prvo je Opačić poslan na Goli otok pa je zadovoljena ,pravna“ strana. Kao da su formalno-pravna pitanja bila problematična u ovo doba i u ovom sistemu. U svojim sjećanjima Opačić ne navodi s kim je doveden na Goli otok, već tvrdi na nikada nije bio zajedno sa Brkićem i Žigićem, te da ih je samo izdaleka vidio na radu. С. Опачић Ћаница, Србин у Хрватској..., 95. Za Opačićev opis boravka na Golom otoku vidi: Исто, 94-96.

46 Špalir je bio svojevrsni obred dočeka na Goli otok.

${ }^{47}$ M. Previšić, $n$. d., 215.

${ }^{48}$ Isto.

49 Č. Višnjić, $n$. d., 359.

${ }^{50}$ U „Petrovoj rupi“, koja se još nazivala „Manastir“ i „R-101“, bili su zatočeni Vladimir Dapčević, Mirko Marković, Savo Zlatić, Dragotin Gustinčić, Branko Petričević Kađa, Milan Kalafatić i drugi. Za više o Petrovoj rupi vidi: M. Previšić, n. d., 427-456. Za memoarski prikaz ovog logora vidi: Dragoljub Jovanović, Muzej živih ljudi 1 (Beograd: Rad, 1990); Milinko Stojanović, Anatomija zločina (Beograd: Stručna knjiga, 1991); itd.
} 
pnu, pa je sada u logoru vrijeme da se daju ti novi detalji. Otuda i naziv ,dopuna zapisnika". Ako i nije postojalo novih detalja ili imena, logoraši su ih morali izmišljati jer bez zadovoljavanja tog kriterija nije bilo izlaska iz logora. U Opačićevom slučaju, čini se da se najviše inzistiralo na „samokritici“, koje objektivno nije bilo u istrazi, ili ne u dovoljnoj mjeri da zadovolji i Udbu i Partiju. Opačić je dao, čak i za udbaške golootočke standarde, nekoliko izrazito dugih (ukupno 112 kucanih A4 stranica!), ,dopuna zapisnika“.

Opačićeve „,dopune zapisnika“ zvuče umjetno i samokritično do razina neuvjerljivosti što nas ne treba čuditi ako iz historiografije i memoaristike o Golom otoku znamo da su logoraši teškim nasiljem prisiljavani na pisanje ,dopuna“, a naravno i njihov ton. Autentičnost dopuna stoga treba biti uzeta s rezervom, ali se lako može pratiti kako one s vremenom bivaju sve više neuvjerljive. Prvo je dao pravu golootočku samokritiku: „Najveća moja nesreća bila je u tome što ja niti sam znao niti mogao da shvatim revizionizam SKP(b) niti učvršćivanje državnokapitalističkog sistema u SSSR-u, ja nisam mogao zamisliti konačne pobede socijalizma u svetu bez moralne i materijalne pomoći Boljševičke partije, njenog autoriteta i dugogodišnjeg iskustva“".51 Potom je na Golom otoku Opačić ,,revidirao“ svoj stav o Žigiću i Brkiću: „Što se tiče njegovog [Žigićevog - op. M. P.] ibeovskog shvatanja, za koje sada znam da je počelo još pojavom rezolucije on ga je toliko vešto krio da ga sve do 1950 godine nisu mogli osumnjičiti ni drugovi iz Politbiroa CK koji su s njim bili u svakodnevnom kontaktu. “52 U zapisniku Opačić je okrivio da je Žigić bio ,glavni akter“ među njima i da ga su ga njegova pozicija, ugled i tumačenja značajno motivirali da preda ostavku. U Opačićevim riječima jasno se vidi koliko je učinkovit sistem na Golom otoku, sistem revidiranja stava pun nasilja: „Ja sam tvrdo ubijedjen da će i Žigić i Brkić prelomiti i to možda vrlo skoro, jer niti atmosfera oko njih, tj. veliki napredak u prevaspitavanju kažnjenika - biv. ibeovaca, koji su sagledali istinu i sve zablude (...) nije ostavio ništa što bi bilo koga od nas zadržalo na liniji rezolucije IB-a. ${ }^{\text {(53 }}$ Prelomiti pod nasiljem!

U nizu daljnjih ,dopuna zapisnika“ Opačić je na sličnom principu detaljno opisivao odnose sa svojim suradnicima i partijskim kolegama poput Bogoljuba Rapajića, Mane Trbojevića, Miloša Kukića, Nikole Basare, Mile Kunića, Bože Rkmana i drugih, pa čak i sa svojom ženom i kćerkom. Da se našao u Moskvi u doba velikih čistki vjerojatno bi mogao i ženu inkriminirati, ali u ovom slučaju to nije bilo na djelu, vjerojatno jer je bilo očito da Dragica Opačić i nema posebne veze sa politikom. Za nju Opačić kaže: „O svom kolebanju na liniji rezolucije ja njoj nisam ništa govorio jer sam ja inače s njom retko razgovarao o stvarima koje nisu za pričanje i drugima. "54 $\mathrm{Na}$ kraju ove serije dopuna Opačić je dao očekivanu partijsku samokritiku tipičnu za golootočke uvjete: „Da li se ja konačno smatram krivim pred Partijom i narodom za svom postu-

\footnotetext{
${ }^{51}$ HDA, 1561, RSUP SRH SDS, Dosje Stanko Opačić (322 926), 188/C.

52 HDA, 1561, RSUP SRH SDS, Dosje Stanko Opačić (322 926), 189-c. (Datum: 27. 6. 1952.).

${ }^{53}$ Isto, $192 / C$.

${ }^{54}$ Isto, 210/C.
} 
pak, obzirom, da se za vreme istrage $u$ Zagrebu ja se nisam izjasnio za IB. Jeste, smatram se krivim i to dvostruko. ${ }^{655}$ Malo kasnije na sljedećim stranicama dopune Opačić zaključuje ,da ja želim raskinuti sa IB-om i poći putem ogromne većine kažnjenika, tj. vratiti se svojoj Partiji i narodu. ${ }^{\text {‘56 }}$

Nešto slično kao i u SSSR-u krajem 1930-ih, i ibeovci su pisali samokritička pisma koja bi potom bila objavljivana u novinama poput Borbe. Slično sadržaju i stilu „,dopune zapisnika“ i ta pisma su bila puna neuvjerljivih fraza $\mathrm{i}$ napadnih samokritika. Nakon torture Golog otoka, a vjerojatno kao jedan od uvjeta za izlazak na slobodu, brojni su visokopozicionirani logoraši Golog otoka pisali ovakva pisma (izjave) poput Save Zlatića, Dragotina Gustinčića ili Bože Ljumovića. ${ }^{57}$ I Opačić je na Golom otoku napisao pismo („Izjava za štampu“) koje na kraju ipak nije objavljeno. Napisao je između ostalog: „Sagledavajući svoju izdaju odlučio sam da iznesem uzroke moje ostavke na dužnosti ministra i da na taj način to prestane služiti kao oružje klevetnicima naše Partije i naroda. “58 Malo kasnije nastavlja: „Kolika je bila moja zabluda vidi se iz toga što sam ja, podnoseći ostavku, znao što činim. Znao sam da u najtežim časovima stvaram našem CK i Partiji još više teškoća. Uhapšen sam 10. septembra i danas dobro vidim da je to bilo pravilno i korisno (...) “. ${ }^{59}$ Uvijek se zapazi slična argumentacija autora pisma o tome kako im je Partija htjela pomoći: „Meni su CK KPH i lično drug Bakarić lično pokušali pomoći, ali sam ja bio jedan od onih koji je prkosno odbijao svaku pomoć. “60 Opačić završava svoje pismo datirano 5. maja 1952. godine: (...) nemam druge želje, nego da svojim radom u granicama svojih mogućnosti, a uz daljnju pomoć Partije, ponovno postanem koristan član našeg socijalističkog društva. “61

Stanko Opačić je, sudeći prema karakteristici, imao uobičajen put u „revidiranju stava“. Vjerojatno nije znao kako funkcionira tehnologija procesa političkog preodgoja na Golom otoku, pa je isprva odbijao pravila igra Udbe, da bi kako je vrijeme odmicalo (vjerojatno pod nasiljem) počeo dopunjavati zapisnik ili biti ,aktivan“ prema drugim logorašima. U dokumentu „Podaci o licima otpuštenih sa radilišta Mermer“ stoji da je „Opačić zadržao svoj stav kakav je imao pred partijskom komisijom i u istražnom zatvoru tj. uporno je odbijao da iskreno priđe raščišćavanju svoje istrage, tvrdeći da on nema veze sa IB-om i da mu nije poznat neprijateljski rad Žigića i Brkića. “62 Promjena je došla s vremenom, jer su rijetki na Golom otoku uspjeli dugo izdržati nasilje: „Koncem 1952. godine Opačić je dao posljednju dopunu i od tada javno istupa kao kažnjenik koji je potpuno raščistio sa svojom istragom i ranijim IB-ovskim shvatanjima." Osim toga, udbaš je zapisao da Opačić ima: „Odnos prema neprijateljskim po-

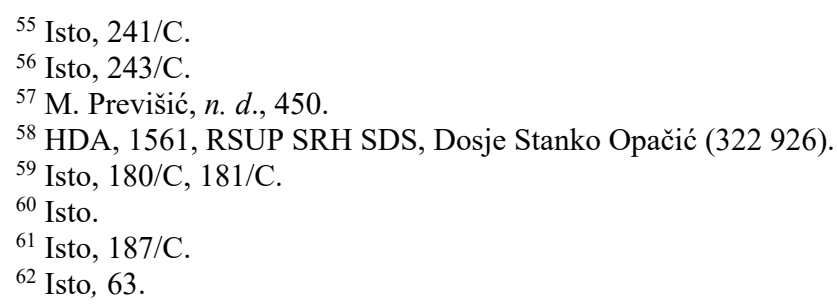


javama i neprijatelju na radilištu [Golom otoku - op. M. P.] pravilan. “63 ك̌ Sto sugerira i aktivnost u nasilju i/ili denuncijacijama. Logoraš Stanko Opačić je na Golom otoku zadovoljio sve kriterije koje je pred njega postavila Udba. Proveo je u logoru ukupno trajanje kazne (24 DKR) i pušten je 25. novembra 1953. godine. ${ }^{64} \mathrm{U}$ završnom dokumentu prije puštanja isljednik je konstatirao: „Prema ranijem dogovoru predlažemo da ga se nakon iste pusti na slobodu, ali smatramo da je na slobodi potreban nad njime stalni nadzor." ${ }^{655}$

\section{„Sloboda“" na Kordunu}

Opačić je zatvorio jedan krug. Onaj politički. Nakon izlaska sa Golog otoka vratio se na Kordun, politika kao i za sve ibeovce više nije bila moguća. Opačić se posvetio zemljoradnji i stolarskom zanatu u Tušiloviću. ${ }^{66}$ Udba ga je, kao i sve druge ibeovce, posebno one važnije, stalno pratila. ${ }^{67}$ Opačić je praćen od svoga povratka na slobodu i jedan od ključnih ljudi zadužen za to bio je Josip Boljkovac, šef lokalne Udbe. ${ }^{6}$ Nakon dolaska u Tušilović doselio se u kuću kod Jake Popović gdje je dobio sobu u kojoj je živio sa ženom. Po selu je obavljao građevinske i stolarske poslove, ali mu je za potonje vlast zabranila rad jer nije imao obrtnicu. Posjedovao je 3,5 rala zemlje koju je obrađivao. U ovo doba udala mu se kćer Vukosava koja je s mužem dolazila u posjet ocu. Opačić nije imao svoju kuću, već je na zemlji izgradio malu kolibu koju je imao namjeru nadogradit pa u njoj živjeti. Samo nekoliko godina ranije živio je u Bosanskoj ulici u Zagrebu, tada i danas elitnom dijelu grada. Opačić je kontaktirao sa seljacima ali kako je Udba imala informacije nije komentirao politiku niti pričao o svojoj političkoj sudbini. Njegovi razgovori su se ticali poljoprivrede. Kada bi ga pitali kako je, odgovorio bi: „Radim i životarim. "69 Tijekom 1955. godine Udba je zabilježila da ga je posjetio njegov bivši šofer, zadržavši se pola sata. Izjavio je da se Opačić jako promijenio, da je mizerno obučen i da ga je jedva prepoznao. Kako da čovjek izgleda nakon Golog otoka? Boljkovac zaključuje da će se preko ,naše mreže“ Opačića i dalje pratiti, ali da je trenutno povučen te ,da se prilagodio okolnostima u kojima živi.“70

Izvještaj iz novembra 1958. govori kako se Opačić družio u selu sa nekoliko starih članova Partije, uglavnom predratnih članova KPJ, ali da Udbi nije poznat sadržaj tih razgovora. ${ }^{71}$ Pomažu si u radu. Na izbore 1958. izašao je sa

\footnotetext{
${ }^{63}$ Isto.

${ }^{64}$ HDA, 1561, RSUP SRH SDS, Informbiro, „Popis“. Postoji Udbina bilješka da je pušten na slobodu u septembru 1953. godine. HDA, 1561, RSUP SRH SDS, Dosje Stanko Opačić (322 926), 68.

${ }^{65}$ HDA, 1561, RSUP SRH SDS, Dosje Stanko Opačić (322 926), 63.

${ }^{66} \mathrm{Za}$ Opačićevo viđenje svoga života nakon izlaska sa Golog otoka vidi: С. Опачић Ћаница, Србин у Хрватској..., 97-105.

${ }^{67}$ Za proces praćenja ibeovaca nakon izlaska sa Golog otoka vidi: M. Previšić, n. d., 485-523.

${ }^{68}$ Josip Boljkovac (1920-2014), sudionik NOB-a, funkcioner Ozne i Udbe, a jedno vrijeme krajem 1960-ih godina gradonačelnik Karlovca. Bio je prvi ministar unutrašnjih poslova Republike Hrvatske nakon demokratskih promjena 1990. godine.

${ }^{69}$ HDA, 1561, RSUP SRH SDS, Dosje Stanko Opačić (322 926), 302/C.

${ }^{70}$ Isto, $302 / \mathrm{C}$.

${ }^{71}$ Isto, $307 / \mathrm{C}$.
} 
ženom i glasao među prvima. Udba je i to pratila. Opačić je osim toga bio i dežurni krivac, što su ibeovci često bili. U decembru 1958. Partija je imala problema oko nedolaska članova na sastanke kao i neplaćanja članarina. To je bio slučaj sa dva člana osnovne organizacije Tušilović (Đipalo i Milić) koji su bili prijatelji Opačića. ${ }^{72}$ Naravno da je milicajac stanice Narodne milicije posumnjao da iza svega stoji Opačić, ali kako i sami zaključuju, to je samo sumnja. Udba je u februaru 1959. godine načinila popis osoba koje su u kontaktu sa Opačićem, te je navela 6 osoba s kojima je on u stalnom kontaktu i 12 s kojima je povremeno. ${ }^{73}$ Praćenje nije imalo velikog smisla jer se Opačić nije bavio politikom, te je živio vrlo povučeno. Opet, Udba je revno sve pratila. Godine 1961. u novembru mjesecu milicioner zapaža da je pred Opačićevu kuću stao automobil (marke FIAT) registracije ZG-41-87 te da su u njemu bila dva muškarca i dvije žene koji su posjetili Opačića. ${ }^{74}$ Ispod izvještaja u dokumentu je zabilješka: „Odmah tražiti u Zbg (Zagrebu - op. M. P.) čija su kola (...)“. ${ }^{75}$ Državna bezbjednost Narodnog kotara Karlovac, nakon 10-ak dana javlja da je automobil vlasništvo Grge Milašinčića, Opačićevog i ratnog druga Većeslava Holjevca kojemu su dva brata poginula u partizanima. $^{76}$ Kako su godine tekle, sudeći prema dokumentima, Opačić je sve manje nadziran iako su mu dolazili gosti koju su ga ispitivali o njegovoj prošlosti, trenutnom životu, ali i razlozima hapšenja zbog IB-a. ${ }^{77}$ Iskusni Opačić nije ništa govorio. Znao je kakve su reperkusije političkog stava i znao je svoju poziciju. U 1965. godini udbaš zaključuje ,,danas je politički pasivan i zadržava se uvijek kod kuće“. ${ }^{78}$ U maju 1966. zaključeno je da su godine ,pasivnosti“ uvjerile Udbu da se njemu ne treba posvećivati veća kontrola, osim one povremene, odnosno da se kontroliranje Opačića da u ruke stanici Narodne milicije. ${ }^{79}$ U svojim sjećanjima Opačić navodi da je 1967. godine bio biran za tajnika i delegata u mjesnom Savezu boraca, a 1969. za općinskog odbornika. ${ }^{80}$

Nakon perioda zatišja Opačić ponovno dolazi u fokus organa službe sigurnosti 1972. godine, kada se nad njime opet otvara „nadzor“. Centar Državne sigurnosti Karlovac sada je ,zaveo“ Opačića kao ibeovca i nacionalista. Nakon raznih pokušaja reformskih pokreta u Partiji te raznih gibanja u društvu (Hrvatsko proljeće - Maspok, Srpski liberali), Opačić je imao svoje interpretacije i reagiranja na novonastalu političku situaciju. U dopisu iz 1975. godine (19. septembar), a koji se reflektira na 1971/1972. godinu i razne ,pojave“ vezane uz to

\footnotetext{
${ }^{72}$ Isto, 308/C.

${ }^{73}$ Isto, $310 / \mathrm{C}$.

${ }^{74}$ Isto, $313 / \mathrm{C}$.

${ }^{75}$ Isto.

${ }^{76}$ Isto, 315/C.

${ }^{77}$ Stanoviti Aleksandar Mikić 27. februara 1964. predao je Udbi izvješće od nekoliko stranica o svom posjetu Opačiću zajedno sa Galovićem, čijeg je oca Opačić poznavao. Pokušali su dobiti od Opačića razne stavove o nekoliko pitanja, ali Opačić je, očito naviknut za udbašku metodologiju, bio suzdržan. Isto, 322-324/C.

${ }^{78}$ Isto.

${ }^{79}$ Isto, 66-67.

${ }^{80}$ С. Опачић Ћаница, Србин У Хрватској..., 103.
} 
razdoblje, Opačić piše: „U vezi pisanja istoriografije posebno je isticao da ,treba pisati i reći istinu, jer se stalno govori neistina, $80 \%$ Hrvata bilo je u ustašama i domobranima, to oni žele sakriti i ako mi šutimo i ne pišemo, ne dokumentujemo, onda će tako i ostati. “61 Dodao je: „Kad ti neki Jure Bilić dođe pa istupi i kaže kao visoki partijski funkcioner, kako su se Hrvati borili na Sutjesci, onda će to kasnije istorija zabilježiti i ostati kao istinito ono što nije tačno“. ${ }^{82}$ Osvrćući se na pisanja i govore o NOB-u, posebno na govor Vladimira Bakarića o ulozi Hrvatske u ratu rekao je: ,a neće da kaže tko su ti u borbi bili i ništa se ne kaže za ovog jadnog Srbina. "83 Posebno interesantno je njegovo gledanje na partizanski pokret u Hrvatskoj 1944. godine, tj. na Andriju Hebranga. Opačić je smatrao da je hrvatsko rukovodstvo 1944. godine zapostavljalo ustaničke krajeve i ,srpski živalj“ $i$ da su ga htjeli još tada likvidirati ali da su to na kraju uspjeli 1948. godine. ${ }^{84}$ Komentirao je trenutnu situaciju u Hrvatskoj gdje se po njegovu viđenju ,sprovodi nacionalizam u oblasti jezika, preko radija i televizije, pisanja, ali da su Srbi nesložni (...) bez obzira što će trpjeti naša nacija. ${ }^{\text {"85 Ko- }}$ mentirajući „Hrvatsko proljeće“ Opačić je zaključio da su se Nikezić i Perović žestoko suprotstavljali Titu i da su se ,rukovodili“ situacijom u Hrvatskoj.

Sljedeća zabilješka je dokument iz septembra 1984. godine Centra državne sigurnosti Karlovac koji iznosi podatak da Opačić pokušava stupiti u vezu sa Vladimirom Dedijerom, ,,izrazivši spremnost da surađuje s njim“ po pitanju svojih iskustava u NOB-u i na Golom otoku. Udbin operativac ostavio je zabilješku, koja sadrži i dozu realnosti: „Za sada nema saznanja o Dedijerovom reagiranju, ali poznavajući njegove metode sakupljanja građe za svoje knjige, vjerojatno će prihvatiti Opačićevu ponudu, pa vas stoga molimo da poduzmete mjere u cilju dobivanja saznanja o njihovim eventualnim kontaktima. "86 Šampion historiografskog žutila Dedijer se ipak nije toliko oslanjao na svjedočenja Stanka Opačića. Jedan od zadnjih zapisa koji smo našli o Stanku Opačiću je onaj iz dosjea ibeovca i logoraša Golog otoka Save Zlatića, ${ }^{87}$ u vrijeme hapšenja saveznog ministra. Nakon Titove smrti, u Jugoslaviji je došlo do otvaranja raznih tabuiziranih tema iz povijesti socijalističke Jugoslavije, pa i javljanja raznih alternativnih pogleda na jugoslavensko društvo i politiku. Sukladno tome, nakon objave Memoranduma SANU, u cilju istraživanja tema koje su se tada činile prilično važne, a imale su snažnu nacionalnu logiku i primjenu, akademik Vasilije Krestić u sklopu svog istraživanja povijesti Srba u Hrvatskoj nakon 1918. godine, a posebno na području Korduna, Banije i Like, tražio je kontakte

\footnotetext{
${ }^{81}$ HDA, 1561, RSUP SRH SDS, Dosje Stanko Opačić (322 926), 69.

${ }^{82}$ Isto, 70 .

${ }^{83}$ Isto, 69.

${ }^{84}$ Isto.

${ }^{85}$ Isto.

${ }^{86}$ Isto, 72.

${ }^{87}$ Usput govoreći, Savo Zlatić bio je šef partizanske bolnice na Petrovoj gori gdje je od samog početka kao bolničarka radila Opačićeva žena Dragica. Kada je umrla 1980. godine, Zlatić je napisao ono što se danas naziva „In memoriam“ u Liječničkom vjesniku krajem 1980. godine. Vidi: С. Опачић Ћаница, Србин у Хрватској..., 166.
} 
od osoba iz tih krajeva. Našao je Opačića koji mu je rekao da je ,plakao što hrvatsko rukovodstvo i Partija nikada nisu osudili Andriju Hebranga koji je bio začetnik uništavanja srpskih kadrova. Kao komunisti su ga osudili, ali ga nikad nije osudila KP, zato što su s njim bili vezani Krajačić, Đerđa i Bakarić. Hebrang ne bi toliko mogao činiti da nije bilo ovih. " ${ }^{\text {(88 }}$ Ubrzo je krenuo raspad Jugoslavije, koji je donio zadnji obrat u Opačićevom životu. ${ }^{89}$

\section{Daleko od Korduna...}

Slučaj Stanka Opačića uklapa se u svoje vrijeme. Sukob sa Staljinom prouzrokovao je razne promjene u poslijeratnoj Jugoslaviji, ali i samoj Partiji. Isto tako, čistka ibeovaca, kako su općim terminom nazvani pristaše Staljina, zahvatila je niz pojedinaca koji nisu isključivo bili pristalice Staljina, već su imali i druge motivacije. Opačićev slučaj dio je tih širih ibeovskih tipologija. Bez obzira na neke veće ili parcijalne historiografske ili publicističke analize slučaja Opačić (te vezanih slučajeva Žigić i Brkić), ova tema zaslužuje daljnju razradu te cjelokupnu historiografsku studiju kakva do danas ne postoji. Ovaj rad trebao bi doprinijeti tim nastojanjima.

Čini se da je Opačić izrastao iz svog okruženja, što je nosilo i političke i razne specifičnosti u mentalitetu. Iako se pridružio KPJ prije izbijanja rata, Opačića je, kao i mnoge druge, oblikovalo iskustvo rata, posebno surovosti na prostoru gdje je živio i ratovao. Kao slabo obrazovani seljak, iz nama dostupnih izvora, razaznajemo da je Opačić i komunizam shvaćao na svoj reducirani način (kao i brojni drugi), kojem je ideologija kao doktrina imala ograničenja. Raskid sa Staljinom bio je ispit za sve u Jugoslaviji, a ujedno je i pokazao sve kontradiktornosti jugoslavenskog komunizma i općenito komunizacije velikog broja partizanskih boraca, koji su se svako iz svojih motiva priključili partizanskom pokretu pa često i KPJ. Kada se promotre zapisnici isljeđivanja ,ministarske trojke“ razabire se da ovu trojicu samo donekle vežu isti motivi; Opačića ipak najviše navodna zapostavljenost ,ustaničkih krajeva“ uz široke aluzije na opterećene nacionalne odnose. Kao što se Šepilov „pridružio“ Maljenkovu, Kaganoviču i Molotovu u pokušaju rušenja Hruščova („I Šepilov koji im se pridružio“) i Opačić se pridružio Žigiću i Brkiću, na samom kraju, iako mu je bila ponuđena opcija, od strane Bakarića, da politički preživi. Nema sumnje da su ,,ustanički krajevi“" jako postradali tijekom rata, a da i u poraću, obnova nije išla željenim tempom, bar ne onim njenih lokalnih lidera, Žigića i Opačića. Postavlja se pitanje, koje objektivno još nije adekvatno historiografski analizirano, koliko je ,zapostavljenost“ imala veze sa tadašnjim teškim ekonomskim stanjem i plansko-centralističkim koncepcijama obnove i razvitka, a koliko s nekim drugim motivima koje se često sugeriraju u dosadašnjim radovima na ovu

\footnotetext{
${ }^{88}$ M. Previšić, $n$. d., 520.

${ }^{89}$ Nakon puštanja sa Golog otoka, Opačić se između ostalog posvetio sakupljanju kordunaških narodnih pjesama, ali i drugih biljega narodnih običaja. Godine 1971. izdao je knjigu Народне пјесме Кордуна (Загреб: Просвјета, 1971). Knjiga je reizdana 1987. godine.
} 
temu. Isto tako, ne treba zaboraviti da je pad Opačića i rezultat staljinističke naravi tadašnjeg režima, i da su smijenjeni ministri bili i sami dio takvog sistema. Godina 1950. bila je uz prethodnu i narednu, vrhunac sukoba sa Staljinom, pa na koncu i vrhunac hapšenja i nasilnog te nehumanog tretmana ibeovaca na Golom otoku, pa stoga ne čudi rigidnost tretmana prema Žigiću, Brkiću i Opačiću, kao obliku unutarpartijske „opozicije“. Jesu li Zlatić, Ljumović, Kalafatić, Hebrang, Žujović, Gustinčić ili Pavić prošli drugačije?

Osim toga, Opačić i nije bio naročito dobar komunist, bar doktrinarno. Njegovo protivljenje ,pravim“ komunističkim mjerama poput otkupa, kolektivizacije, pa onda raznih obrazovnih mjera, po njegovu sudu zapostavljanja ćirilice, danas ga stavljaju u jedan nacionalni kontekst pa i u poziciju prikladnu za nekog epskog junaka, toliko raširenog izričaja na tom području. Na koncu, još su mu za života spjevani stihovi, koji najvjerojatnije nisu izašli iz Agitpropove kuhinje. Kada je Partija odlučila da je njegov politički put završen, nije bilo teško naći argumente koji su ga trebali difamirati. Za razliku od Žigića koji se nije vratio sa Golog otoka te je svoj stav platio glavom, Opačić je slomljen pušten na slobodu u Kordun, a dokumenti tajne policije o njegovu praćenju nakon logora pa sve do 1980-ih daju možda jasniju sliku o Opačiću i njegovu političkom mentalitetu. Daleko od politike, daleko od Zagreba i Beograda, on je, bar kako je Udba zapisala, sve više tumačio događaje u nacionalnom ključu, možda pomalo u crno-bijelom kordunaškom pogledu kreiranom boreći se protiv ustaških pogroma srpskog stanovništva na tom području. U njemu, čini se, nije ostalo ništa od komunizma (ako kao suprotni pol uzmemo Vladu Dapčevića), sudeći po zapisima iz 1970-ih, a posebno iz 1980-ih godina kada se, bar posredno, preko davanja svojih sjećanja, upregnuo u jednu strategiju koja će imati značajne učinke za Jugoslaviju. Koliko god gledanje bilo ahistorijsko, treba se postaviti pitanje o naravi Opačićeva komunizma što je samo uvod za puno veću i važniju analizu o sadržaju jugoslavenskog komunizma, emocionalno izgrađenog u ratu, a doktrinarno nametnutog $\mathrm{u}$ poslijeratnoj staljinizaciji. Na koncu, nešto se tragično isprepliće u Opačićevoj sudbini. Ovaj kordunaški ratni lider, poslijeratni ministar i visoki partijski funkcioner, logoraš Golog otoka i opet obični seljak, izbijanjem rata na području Hrvatske otišao je sa Korduna u daleki Šabac gdje je 1994. umro i sahranjen.

\section{REFERENCE}

- Banac, Ivo. With Stalin against Tito. Ithaca and London: Cornell University Press, 1988.

- Bekić, Darko. Jugoslavija u hladnom ratu. Zagreb: Globus, 1988.

- Bondžić, Dragomir, prir. Novinarska i diplomatska škola 1948-1953. Beograd: Institut za savremenu istoriju, 2013.

- Bondžić, Dragomir. „Kordun u socijalističkoj Jugoslaviji“. U: Kordun - Od vojne granice do Republike Srpske Krajine. Ur. Momčilo Pavlović, 317-494. Beograd: Institut za savremenu istoriju, 2018. DOI: 10.29362/2275.bon.317-478 
- Dedijer, Vladimir. Novi prilozi za biografiju Josipa Broza Tita, Treći tom. Beograd: Rad, 1984.

- Jandrić, Berislav. Hrvatska pod crvenom zvijezdom. Zagreb: Srednja Europa, 2005.

- Jovanović, Dragoljub. Muzej živih ljudi 1. Beograd: Rad, 1990.

- Kisić Kolanović, Nada. Hebrang iluzije i otrežnjenja. Zagreb: Institut za suvremenu povijest, 1996.

- Milatović, Mile. Slučaj Andrije Hebranga. Beograd: Kultura, 1952.

- Mitrović, Momčilo. „Tri ibeovca u Hrvatskoj 1950. godine“. Tokovi, br. 1-4, (1998), 179-191.

- Opačić Ćanica, Stanko. Narodne pjesme Korduna. Zagreb: Prosvjeta, 1971.

- Opačić Ćanica, Stanko. Srbin u Hrvatskoj - Kazivanja kordunaškog seljaka, ratnika, ministra, osuđenika... Beograd: Litera, 1989.

- Previšić, Martin. Povijest Golog otoka. Zagreb: Fraktura, 2019.

- Roksandić, Drago. Srbi u Hrvatskoj. Zagreb: Vjesnik, 1991.

- Stojanović, Milinko. Goli otok - Anatomija zločina. Beograd: Stručna knjiga, 1991.

- Vesović, Milan. „Stanko Opačić Ćanica: putevi i bespuća kordunaškog seljaka“. Istorija 20. veka, br. 1, (1996), 153-162.

- Višnjić, Čedomir. Partizansko ljetovanje. Zagreb: Prosvjeta, 2003.

- Vojnović, Branislava, prir. Zapisnici Politbiroa Centralnog komiteta Komunističke partije Hrvatske, Sv. 2. Zagreb: Hrvatski državni arhiv, 2006.

MARTIN PREVIŠIĆ, PhD, docent

Faculty of Philosophy, University of Zagreb

Zagreb, Republic of Croatia

martinprevisic@gmail.com

\section{THE FALL OF STANKO OPAČIĆ ĆANICA - FROM KORDUN TO LABOUR CAMP AND BACK AGAIN}

\section{Summary}

Paper analyses political fall of Stanko Opačić Ćanica in year 1950, his arrest, interrogation, incarceration on Goli otok labor camp and subsequent surveillance after the release by the Yugoslav secret police. The paper is based on State security documents, scientific literature, published documents and oral history of former Goli otok inmates. The goal of this paper is contribution to the analysis of causes and consequences of Opačić's political fall, closely tied to the fate of so called "ministerial troika", group of Serbian ministers in the government of Peoples Republic of Croatia. This case is, of course, part of wider analysis on causes of purges of real alleged supporters to Soviet Union during the Tito-Stalin split.

KEYWORDS: Stanko Opačić Ćanica, Rade Žigić, Duško Brkić, Udba, Goli otok, Yugoslavia 